\title{
ТІЛЕСНИЙ АСПЕКТ ІДЕЙНО-КОНЦЕПТУАЛЬНОГО ВИМІРУ ЖУРНАЛУ «ХАРПЕРС БАЗАР» (США)
}

\author{
Наталія Михайлів \\ Львівський національний університет імені Івана Франка, \\ вул. Генерала Чупринки, 49, 79044, Львів, Україна, \\ e-mail: ozerna.n9@gmail.com \\ https://orcid.org/0000-0001-8314-0196
}

В статті на прикладі журналу «Харперс Базар» (США) проаналізовано репрезентацію жіночої тілесності у гендерно маркованому глянці; з'ясовано, що термін «гендерно маркований (жіночий) журнал» відображає соціальну грань жіночої тілесності, чільне місце в якій посідає краса. Виокремлено і розкрито зміст естетичного та екзистенційно-соматичного аспектів краси тілесності, встановлено умови останньої та доведено синтез обидвох як нерозривної єдності тіла, душі та духу жіночої гендерної одиниці.

Ключові слова: тілесність, жіночий журнал, гламур, краса, екзистенційно-соматична краса.

Bcmyn. Абсолютизація тілесності, що відбувається в останні десятиліття, призвела до утвердження кічу як обов'язкового атрибуту життя, кристалізації демонстративного типу особистості як взірцевого та вкоріненого явища гламуру. Жіноче тіло нерідко розглядають виключно як об'єкт естетичного сприйняття. Ці тенденції розгортаються на теренах глянцевої журналістики, формують стиль життя читачів, паралельно проростаючи об'єктами неминучої критики через показовість, не підтверджену сенсом.

Buхідні передумови. Розвідка базується на наукових положеннях, викладених в працях таких дослідників, як Е. Берк, М. Гудова, Й. Лось, І. Кікінеджі, Г. Почепцов, В. Смеюха. Проблематика репрезентації жіночої тілесності відповідним глянцем випливає з розуміння останнього як осередку гламурного світу та «хронотопу уявного повсякдення» [4]. Через визнання відповідності жіночої періодики інтересам жін$\kappa u$, значного впливу, що його здійснюють на жіночу аудиторію журнали, В. Смеюха трактує їх як видання про «спосіб життя, котрий базується на матеріальних цінностях» [12, с. 42], присвоюючи читачці «Харперс Базар» «елегантність стилю», виокремлюючи серед пріоритетів останньої «високу моду, дібране коло спілкування, відомих модельєрів» [13, с. 174]. Г. Почепцов вважає гламур явищем штучного світу, де головною ознакою є посмішка, а похмурість витісняється [10, с. 396]. В означеному підході до вивчення глянцевої жіночої періодики й журналу «Харперс Базар»

(с) Михайлів Н., 2019

Наукове рецензування і рекомендація до друку - доц. Хоменко Т. М. 
зокрема, тілесне начало протиставляється духовному, а елементи антропологічної тріади сутності людини (тіло, душа, дух) розглядаються розірвано, в ізоляції один від одного. Зважаючи на це неорганічне протиставлення та виходячи 3 того, що важливо постійно звіряти «вагомі» слова з реаліями динамічного світу, аби уточнювати маршрут доби [8, с. 96], метою цієї статті є розв’язання актуальної теоретико-практичної дилеми: «тіло або душа» на прикладі журналу «Харперс Базар» (США). Мета зумовлює такі завдання: 1) розглянути основні теоретичні підвалини поняття «гендерно маркований журнал»; 2) описати репрезентацію жіночої тілесності на сторінках журналу «Харперс Базар» (США); 3) здійснити аналіз подачі феномену краси 3МІ на прикладі журналу «Харперс Базар»; 4) з'ясувати роль антропологічних феноменів душі та духу у формуванні естетичної тілесності на прикладі героїнь матеріалів журналу «Харперс Базар»; 5) виявити чинники протяжної естетичної краси; 6) окреслити співвідношення краси тілесності в інтерпретації сучасного глянцю та богословського розуміння естетичної краси.

Емпіричну основу дослідження складають матеріали примірників журналів «Харперс Базар» (видання США): за грудень-січень 2017-2018 рр., лютий 2018 року та квітень 2018 року.

Одержані результати. Поряд 3 націленістю на створення домашнього затишку, охайністю, емоційністю, прагненням виявляти турботу жінкам притаманні переважно підвищена, в порівнянні з чоловіками, увага до власної зовнішності, зацікавленість новітніми тенденціями їі облагородження. Жінці властиво розкривати, подавати та реалізувати себе за посередництвом тілесності, з акцентом продемонстрованих взірців й залученням творчого підходу. Таку поведінку жінки охоплюють переважно типові норми, а їі формування - тривалий процес, із залученням колективного (1) та індивідуального (2) аспектів. Перший полягає в засвоєнні норм поведінки, притаманних власне жінці. Статеворольова ідентифікація як багатомірний та інтегративний психологічний феномен відбувається в процесі соціалізації дитини під впливом сім’ї, школи та засобів масової інформації, виступає як соціальна та індивідуальна персоналізація гендерного «Я» [6, с. 301]. У цьому контексті доцільно застосовувати поняття «гендер», адже якщо поняттям «стать» описують анатомічні, фізіологічні, психічні та поведінкові риси людей, то «гендер» - це соціальна стать, соціально детерміновані ролі, ідентичності і сфери діяльності чоловіків і жінок, які залежать від соціальної організації суспільства [14, с. 128]. Норми жіночості та чоловічості, які охоплює поняття «гендер», своєю чергою, характеризуються такими ознаками, як змінність, варіативність, культурна зумовленість [3, с. 13]. Натомість «стать» - більш вузьке і статичне поняття, застосування якого звузило б рамки наукового пізнання у розвідці репрезентації жіночої тілесності на сторінках відповідного глянцю. Доходимо висновку, що термін «гендерно маркований (жіночий) журнал» відображає соціальну грань жіночої тілесності, зумовлену соціумом, його культурою та прогресом. Індивідуальний аспект в самопрезентації жінки як тілесної одиниці розкривається через виокремлення себе у масі собі подібних, усвідомлення власної тілесної індивідуальності, застосування творчого підходу в процесі її удосконалення.

Журнал «Харперс Базар» (США) є гендерно маркованим (жіночим) журналом, який займає широку нішу в масиві жіночої періодики США. «Харперс Базар» характеризує аудиторна ознака - він призначений для жінок зі статками, вищими за серед- 
ні. Позиціонування жінки в соціумі, зумовлене, значною мірою, ЗМІ, здійснюється у тому числі і за посередництвом тілесності. «Харперс Базар» рясніс зображеннями жінок різного віку, здебільшого моделей та відомих особистостей. Жіночу тілесність видання репрезентує на своїх сторінках як еталон, взірець для наслідування; через жіночу тілесність подає свої товари реклама. Центральною ідеєю цієї репрезентації постає краса. Потрібно зазначити, що елітам усіх епох іманентно притаманне прагнення високоорганізованого буття, сповненого рафінованих атрибутів, чільне місце серед котрих належить власне красі. Після реалізації основних, невід'ємних потреб, як-от у харчуванні, теплі, злагоді, у жінки з'являється прагнення актуалізувати потреби наступного рівня. На ньому перебуває краса як соціальний феномен. Естетична тілесність символізує успішність, добробут, гармонію, смак. Краса - сукупність явищ, які милують зір, слух; все прекрасне, гарне (1); сукупність зовнішніх рис, фізичних якостей людини, які справляють приємне враження (2) [11, с. 716]; те, що є прикрасою, гордістю чого-небудь [15, с. 466]. Увага до тілесності і набуття означених її властивостей $є$ фактором жіночої самооцінки та соціального визнання. Відтак, культивування у пресі для жінок, чий дохід перевищує середній, краси тілесності постає закономірним та невіддільним атрибутом елітарної преси з часу її заснування. Ще в середині XIX століття у США бездоганні леді, виховані нескінченним потоком дамських періодичних видань, стояли в самовдоволеному очікуванні нової порції журнальної продукції [5, с. 74]. Попри те, що журнал - відкрита динамічна система, що з часом зазнає зовнішніх (політичних, економічних, соціальних) та внутрішніх (редакційних) впливів, тенденція до культивації ідеї краси на його сторінках зберігається. Адже краса в бутті жінки - це і реальність тілесності; ця реальність завжди екзистенційно зумовлена, тому в контексті дослідження краси в бутті жінки евристично плідним $є$ використання не лише словосполучення «краса тілесності», але й поняття «екзистенційно-соматична краса» [7, с. 191]. В такий термінологічний спосіб підкреслюється взаємозумовленість внутрішніх (духовних) та зовнішніх (тілесних) явищ в структурі гендерної (жіночої) одиниці. Тісний взаємозв'язок психічних і соматичних процесів в організмі вивчає психосоматика, одне з найважливіших завдань якої - дослідження ролі психологічних факторів у виникненні тілесних захворювань [9, с. 34]. Досліджено, що злагоджена діяльність людського тіла як біологічної одиниці позначається і на зовнішньому аспекті тілесності.

Звернімося до репрезентації жіночої тілесності в журналі «Харперс Базар» (США) та, з огляду на екзитенційно-соматичну зумовленість краси, спробуємо виявити екзистенційно-соматичні опори естетичної краси героїнь видання. Квітневий номер американської версії «Харперс Базар» вміщує матеріал під назвою «Кармен. Неймовірна у будь-якому віці», який умовно можна розділити на дві частини: 1) стаття про 86-річну Кармен Дель Орефіс, найстаршу у світі модель, яка працює впродовж 73-х років; 2) грамурні світлини, на яких зображено героїню. Центральна ідея публікації - позачасова краса як феномен реальності. Другорядні - витривалість перед об'єктивом, народження кохання серед інтриг за лаштунками модельного світу, висока працездатність героїні. Аналогічну структуру має матеріал «Високий політ Джей Ло», на світлинах якого 49-річна співачка і продюсер демонструє ефектну, здорову, доглянуту тілесність. В одязі від «Гуччі», «Джамбатиста Валлі», «Емпоріо Армані» тощо, ікона стилю, 62-річна модель Іман постає знавцем трендів, легендою модельного бізнесу та борцем за права чорношкірих моделей [20, с. 200]. Поза фо- 
тосесією «найзатребуваніша у світі супермодель» Кендал Дженнер в інтерв’ю колезі Карі Делевінь, вміщеному в лютневому номері, виказує стурбованість світовими жахіттями, відсутністю любові серед людей, сварками онлайн, і тим, як важко залишатися позитивною [17, с. 108-110]. Спільною ознакою перелічених матеріалів $є$ зосередження уваги на ментальних установках героїнь, котрі репрезентують себе світові передусім візуально, за посередництвом краси тіл. У статті «Джей Ло літає високо» на прикладі героїні демонструється сила позитивного мислення, працелюбності та мотиваційних мантр - «Жодних обмежень крім неба», «Життя коротке, здійснюй мрію» та інших, що підносять Лопес «на верхівку особистісно та професійно» [19, с. 131-136]. «Учись казати «ні» і йти геть від речей, які тобі не слугують. «Ні» - це завершене речення. Ти не мусиш пояснювати себе», - так Іман розкриває найкращу пораду, що їі коли-небудь отримувала [20, с. 200]. У статті «Анджеліна Джолі: показ надії» квітневого номера йдеться про модне шоу, яке спеціальний посол Управління Верховного Комісаріату ООН у справах біженців і «найгламурніша жінка на планеті» організувала на підтримку біженців-ремісниць [16, с. 190-193]. В матеріалі «Весілля моїх найкращих друзів» лютневого номера розміщено світлини 3 весілля Еллі Галфайгер, доньки всесвітньо відомого дизайнера Томмі Галфайгера. Автор наголошує на спільності поглядів пари і на успішності зокрема, яка, на їх думку, є величною, однак якщо ти не вмієш по-справжньому насолоджуватись життям і поставити свою сім'ю, друзів і натуру понад усім іншим (виділ курсивом наш - Н.М.), тоді ти справді робиш щось не так [21, с. 80]. У рубриці «Новини» груднево-січневого номера за 2017-2018 рр. донька Голді Хоун, гламурна акторка Кейт Хадсон, розповідає про участь спільно з Майклом Корсом у Світовій Програмі Харчування Об’єднаних Націй: «Вважаю, що це - один з ключових компонентів, що їх ми губимо в цьому «взаємопов'язаному» світі: коли допомагаєш людям з фундаментальною потребою в їжі, переступаєш через міст» [22, с. 208]. Як бачимо, ідеї «Харперс Базар» (США) зосереджуються не стільки довкола тілесності як феномену, скільки виражають більш глибокі особистісні значення - в журналі системно розміщуються статті психологічного, світоглядного, благодійного спрямування, в центрі яких - гламурні жінки. Означена онтологічна реальність видання свідчить про інтерес аудиторії до внутрішнього світу героїнь, зокрема, принципів їхнього життя, мотивації, способу мислення, соціальної діяльності тощо. Відомі жінки демонструють не лише естетичну красу тілесності, а й силу особистості, внаслідок чого конкретна тілесно-духовна індивідуальність переростає в об'єкт загального зацікавлення, взірець для наслідування, чинник формування масового світогляду.

Співвідношення на сторінках «Харперс Базар» (США) двох складових частин статей про відомих жінок, дає підстави зробити такі висновки щодо ідейно-концептуального наповнення цих матеріалів: а) виплекана тілесність $є$ їх обов'язковим компонентом; б) краса тілесності постає репрезентативною і водночас екзистенційно-соматичною ознакою; в) екзистенційно-соматична краса є результатом невпинної інтенсивної духовної роботи, причому остання постає первинною.

На цю пору краса нерідко підміняється поняттям «гламур», який як явище набув поширення з початком нового тисячоліття із одночасною і неминучою критикою за показовість, не підтверджену сенсом. Відомо, що гедонізм не здатен породжувати щось важливіше за сьогочасну насолоду, гламур же, як зазначає Г. Почепцов, «замкнений на себе». «Це одна точка часу і простору. Отже, відбувається звужен- 
ня часового обрію до завдань цього дня... Створюється безпроблемний світ, хоча i штучний. В безпроблемному світі панують інші настрої, тут посмішка стає головною ознакою, похмурість залишається за кордонами цього штучно створеного світу» [10, с. 396]. Не заперечуючи цієї позиції, зазначимо, що гламур залишається затребуваним способом тілесного самовираження і читачки «Харперс Базар», і героїнь матеріалів журналу. Тимчасом, в умовах звуження часового обрію до короткострокових завдань, насолоди життям, яка не розмикається, залишена поза гламурним кадром похмурості екзистенційно-соматична краса жінки з часом нівелюється, унеможливлюється плекання передусім краси духовної, яка згодом опосередковується тілесною. Доконечно відомо, що життя передбачає довгостроковий багатовекторний вимір, буття ж в одній точці часу і простору позбавляє людину перспективи. Водночас, на прикладі героїнь «Харперс Базар» - Кармен Дель Орефіс, Іман, Дженіфер Лопес, Анджеліни Джолі - спостерігаємо за гармонійною єдністю на цей час таких властивостей предмета (жінки), сприйняття яких викликає у читача захоплення - красою тілесності; за явищем, яке милує зір, сукупністю зовнішніх рис, які зумовлюють приємність враження: «Я знайома з Кармен більш як 20 років. Та навіть сьогодні у її компанії від неї неможливо відвести очей. Настільки вона вражаюче гарна» $[18$, с. 196]. «Вдача, - зазначає з приводу взаємообумовленості соматичних та естетичних процесів Е. Берк, - надає деякої постійності виразові обличчя; помічено, що воно досить точно відповідає їй, тим самим вплив деяких приємних якостей душі здатний з'єднатися із впливом таких самих якостей тіла...» [1, с. 144]. Попри розпад сім’ї і втрату органів тіла продовжує цвісти екзистенційно-соматична краса філантропа А. Джолі.

Красу відомих героїнь «Харперс Базар» пізнаємо насамперед за посередництвом людського естетичного (зорового) відчуття (естетичний аспект тілесності), їхня гламурність очевидна. Проте, як феномен, що не обходиться без вольових і духовних зусиль, екзистенційно-соматична краса безальтернативно потребує звернення до універсальних цінностей - Добра, Краси довколишнього світу, Любові, Правди. До головних параметрів екзистенційно-соматичної краси відносимо виразність, стійкість та тривалість. Тривалість краси у випадку К. Д. Орефіс складає 73 роки, Дж. Лопес - близько 25 років, Іман - 45. Екзистенційно-соматична краса вимагає акумуляції фізичного й морального ресурсу у часовій протяжності, наявності в жінки відповідних психологічних якостей, провадження життя у злагоді з універсальними цінностями. Як стійке та протяжне явище екзистенційно-соматична краса несумісна 3 обмеженістю буття однією точкою часу і простору, посмішкою безпроблемного, штучного світу й похмурістю реального, звуженням часового обрію до завдань цього дня.

Переклад слова «glamour» (гламур) з англійської мови - «чари», «чарівність», «романтичний ореол», «ефектність». Однак краса, на відміну від гламурності, $є$ цілісним феноменом, тоді як гламурність - це не лише прикрашене буденне буття людини, що видає себе за граничне буття, а й саме граничне буття; лише в метаграничному вимірі людського буття гламурність трансформується в справжню красу, що об'єднує красу світогляду, красу вчинків та красу відносин (виділ курсивом наш Н. М.); саме в цьому бутті людина набуває цілісну красу, яка протистоїть розірваності гламурності [7, с. 15]. 
На прикладі героїнь «Харперс Базар» спостерігаємо актуалізацію зовнішньої краси на базі внутрішньої (екзистенційно-соматичний аспект тілесності), коли тілесність постає своєрідним показником неповерхневого благополуччя; красу, яку уможливили краса світогляду, краса вчинків і краса відносин. Виникають підстави вважати, що в екзистенційно-соматичну красу героїнь журналу «Харперс Базар» як комплексне морально-психофізичне явище переросли збережені впродовж тривалого життєвого періоду: 1) злагоджена діяльність тіла як біологічної одиниці; 2) провадження життя згідно з Одвічними, універсальними цінностями; 3) психологічна стійкість. Таким чином, жіноча екзистенційно-соматична краса, що характеризується стійкістю та тривалістю, вимагає одночасних потуг від трьох елементів антропологічної тріади людини: у першому випадку це - тіло, у другому - дух, в третьому душа.

Звіримо «вагомі» слова з реаліями динамічного світу. Останні відсилають до Слова, яке було спочатку, синтезу матеріального та ідеального, в якому примат належить другому началу. «Вся сотворена чи то матеріяльна, чи духовна дійсність $\epsilon$ іконою Божою, а тим самим відблиском Божої краси. Одначе людська істота з огляду на свій розум і раціональність, з огляду на свобідну волю і з огляду на естетичне почуття, яким вона сприймає красу, є особливою Божою іконою, сотвореною на образ і подобу Божу... Тому бути внутрішньо і зовнішньо гарним і творити красу - це конечна егзистенціальна обставина і моральне зобовязання (виділ курсивом наш - Н. М.) кожної раціональної істоти» [2, с. 95]. Далі зазначається, що «Божий син Господь Ісус Христос через вочоловічення є Богочоловіком, або воплоченим Божим Словом, який об'являє себе досконалою людиною і джерелом людської зовнішньої і внутрішньої краси» (виділ курсивом наш - Н. М.) [2, с. 94-95]. Тож будьте досконалі, як Отець ваш небесний досконалий (Мт. 5:48). Безпосередньо в Новому Завіті описано позитивні зміни зовнішності як вияв духовної світлості Сина Божого Ісуса Христа: «По шістьох днях узяв Ісус Петра, Якова та Івана, його брата, повів їх окремо на високу гору і преобразився перед ними: обличчя його сяяло, наче сонце, а одежа стала білою, наче світло» (Мт. 16:2-3). Тілесність у цьому випадку постає феноменом відображення внутрішньої сутності і Святості Боголюдини, зливаючись з останньою та засвідчуючи іiі. Результат описаних змін візуально постав естетичною тілесністю явищем, яке милує людський зір, тілесністю соціально зумовленою, охопленою, водночас, терміном «екзистенційно-соматична краса».

У підсумку зазначимо, що зовнішня краса не лише не протистоїть внутрішній, вдаючись в аскезу чи абсолютизуючись - обидві об'єднуються, синтезуються та засвідчують одна одну, перетікаючи в антропологічну цілісність тіла, душі та духу. На прикладі проаналізованих матеріалів журналу «Харперс Базар» (США) як явища 3МI, що віддзеркалює динаміку суспільних відносин, спостерігаємо за актуалізацією в його ідейно-концептуальному вимірі статичної та нерозривної єдності елементів антропологічної тріади людини.

Деструктивним тенденціям в структурі жіночої гендерної одиниці можна дієво протиставити усвідомлення себе як цінності, визнання власної антропологічної цілісності, в якій тілесності відведено не меншу вагу, аніж душі і духові. Жіночому глянцеві як чиннику гендерного самоусвідомлення, самоутвердження та самовдосконалення в цьому процесі належить провідна роль. Подальші розвідки в цьому напрямі дозволять утвердити в ЗМІ погляд на жіночу гендерну одиницю як на цілісне 
явище, а на Красу - як на універсальну цінність, яка, поряд з Добром, Правдою та Справедливістю, підлягає культивації незалежно від умов динамічного світу.

Висновки. В процесі гендерної самоідентифікації залучаються колективний та індивідуальний чинники, внаслідок чого кристалізується соціальна стать (гендер). Гендерно маркований (жіночий) журнал «Харперс Базар» (США) репрезентує жіночу тілесність у взаємозв'язку з внутрішньо-вольовими й духовними процесами, ефективність яких переростає в силу персоналії як світоглядного феномену і взірця для наслідування, чинника формування масової культури. До виокремлення підлягають два аспекти краси тілесності, репрезентованої на сторінках «Харперс Базар» (США): естетичний (зовнішня краса) та екзистенційно-соматичний як комплексне морально-психофізичне явище. Репрезентація жіночої тілесності в досліджуваному глянці відповідає закономірній потребі жінки, яка переступила етап задоволення базових потреб, в красі. Умовами екзистенційно-соматичної краси як протяжного явища є: біологічна схоронність, психологічна стійкість та звернення до універсальних цінностей. Раціональний жіночий погляд на власну гендерну ідентичність передбачає, поряд з плеканням душі і духу, увагу до тілесності, причому остання нарівні 3 першими постає моральним зобов'язанням. У рамках ідейно-концептуальної моделі «Харперс Базар» естетична та екзистенційно-соматична краса не протистоять одна одній, проте синтезуються у нерозривну єдність антропологічної тріади жіночого гендеру, що її відображає глянець.

Теоретико-практичний результат дослідження полягає в збагаченні творців та теоретиків жіночої преси знаннями щодо ідейно-концептуальної спрямованості жіночого глянцю, який би максимально відповідав глибинним потребам гендеру. Подальші розвідки в цьому напрямі дають змогу утвердити в ЗМІ погляд на жіночу гендерну одиницю як на цілісне явище, а на Красу - як на універсальну цінність, яка, поряд з Добром і Правдою, підлягає культивації, незалежно від динаміки світу.

\section{REFERENCES}

1. Берк Э. Философское исследование о происхождении наших идей возвышенного и прекрасного: пер. с англ. / Э. Берк; общ. ред., вступ., статья и коммент. Б. Мееровского. М. : Искусство, 1979. 237 с.

2. Біланюк П. Божа істина, краса і любов / П. Біланюк. Дрогобич : Видавнича фірма «Відродження», 1995. 378 с.

3. Гендер для медій: підручник із гендерної теорії для факультетів журналістики та інших соціогуманітарних спеціальностей / За ред. М. Маєрчик, О. Плахотнік, Г. Ярманової та ін. К. : Критика, 2017. 218 с.

4. Гудова М. Женские глянцевые журналы: хронотоп воображаемой повседневности: монографія / М. Гудова, И. Ракипова. Екатеринбург : Изд-во Урал. ун-та, 2010. $242 \mathrm{c}$.

5. История мировой журналистики/ кол. авторов: А. Беспалова, Е. Корнилов, А. Короченский [и др.]. М. ; Р н/Д : Изд. Центр «Март», 2003. 432 с.

6. Кікінеджі О. Гендерна ідентичність в онтогенезі особистості: монографія / О. Кікінеджі. Тернопіль : Навчальна книга - Богдан, 2011. 400 с. 
7. Крилова С. Краса людини: особистість, сім'я, суспільство (соціально-філософський аналіз): монографія / С. Крилова. Ніжин : ТОВ «Вид-во “Аспект-Поліграф"», 2011. 344 с.

8. Лось Й. Перспективи світоглядної публіцистики : навчальний посібник / Й. Лось. Львів : ЛНУ імені Івана Франка, 2014. 294 с.

9. Міхеєнко О. Валеологія: основи індивідуального здоров'я людини: навчальний посібник / О. Міхеєнко. Суми : ВТД «Університетська книга», 2009. 400 с.

10. Почепцов Г. Від Facebook’y і гламуру до Wikileaks: медіа комунікації / Г. Почепцов. К .: Спадщина, 2012. 464 с.

11. Словник синонімів української мови. Том 1 / [А. Бурячок, Г. Гнатюк, С. Головащук]. К. : Наукова Думка, 2001. 1040 с.

12. Смеюха В. Женские СМИ и новые медиа: учеб. Пособие / В. Смеюха. Р н/Д, 2015. $96 \mathrm{c}$.

13. Смеюха В. Процессы идентификации и женская пресса: монографія / В. Смеюха. Р н/Д : Росиздат, 2012. $318 \mathrm{c.}$

14. Смеюха В. Теория и практика массовой информации: учеб. пособие / В. Смеюха. Ростов н/Д, 2015. $87 \mathrm{c}$.

15. Творчество: от биологических оснований к социальному и культурному феноменам / ред. Д. Ушакова. М. : Изд-во «Институт психологии РАН», 2011. 736 с.

16. Тлумачний словник української мови: понад 12500 статей (близько 40000 слів) / ред. В. Калашника. 2-ге вид. Х. : Прапор, 2004. 992 с.

17. Cohn A. Angelina Jolie: runway of hope / A. Cohn//Harper's Bazaar. New York: Hearst Communications, Inc. April, 2018, issue no. 3662. P.190-193.

18. Delevingne K. Naked truth/ K. Delevingne // Harper's Bazaar. New York: Hearst Communications, Inc., February, 2018, issue no 3660. P. 105-113.

19. Fiori P. Carmen. Fabulous at any age / P. Fiori//Harper's Bazaar. New York: Hearst Communications, Inc., April, 2018, issue no 3662. P. 194-197.

20. Gonzales Whitaker I. J.Lo's flying high / I. Gonzales Whitaker // Harper's Bazaar. New York: Hearst Communications, Inc., April, 2018, issue no 3662. P. 160-167.

21. Henson T. Iman / T. Henson // Harper's Bazaar. New York: Hearst Communications, Inc, April, 2018, issue no 3662. P. 198-203.

22. Jagger J. My best friend's wedding / J. Jagger // Harper's Bazaar. New York: Hearst Communications, Inc., February, 2018, issue no 3660. P. 80-81.

23. Watch hunger stop // Harper's Bazaar. New York: Hearst Communications, Inc, December 2017 / January, 2018, issue no. 3659. P.208. 


\title{
CORPORAL ASPECT OF IDEA-CONCEPTUAL MEASURING OF «HARPER'S BAZAAR» MAGAZINE (USA)
}

\author{
Natalya Mykhayliv \\ Ivan Franko National University of Lviv, \\ Generala Chuprynky Str., 49, 79044, Lviv, Ukraine \\ e-mail: ozerna.n9@gmail.com \\ https://orcid.org/0000-0001-8314-0196
}

In the article on the example of the «Harper Bazar» magazine (USA), the representation of female corporeality by gender-labeled glossy magazine was analyzed, it was found that the term «gender-stamped» female magazine reflects the social facet of female corporeality, a prominent place in which beauty takes, departed and ostended the content of the aesthetic and existentialsomatic aspects of the beauty of corporeality, the conditions of the latter established and the synthesis of both is proved as the inseparable unity of the body, soul and spirit of the female gender unit, examples of which are reflected in the materials of the edition.

The author reveals common characteristic of the analyzed features of «Harper Bazar», that is concentration of an attention around mental arrangements of its heroines (Carmen Del'Orefice, Jennifer Lopez, Angelina Jolie, Iman, Kate Hudson), who represents themselves to the world first with their corporeality. Therefore there has been made a conclusion that beauty is to be considered not only as the aesthetic phenomenon, but as a work of three elements of anthropological triad of human being, formerly they are soul and spirit. While disengaged from the entire perception of human being, the phenomenon of glamor, which has been subjected to stunning critics for the demonstration not confirmed by a sense, is not able to maintain one with long-lasting perspective. As life provide multi-vector dimension, thus, rising durable beauty demands deeply interior forces.

It is emphasized that «Harper Bazar's» features corresponds to the demands of its auditory that consists of women, whose income increases a middle one. Its issues provide beauty theme as one of the central. At the same time the features of «Harper Bazar» reflect deep personal meanings, fixing on psychological, world-view and philanthropic aspects of the personalities of the heroines. Rising beauty as the lasting phenomenon consists of three basic elements: coordinated activity of body, willing efforts and the work of spirit as the indissoluble unity of anthropological triad of human being, that is elucidated in idea-conceptual filling of «Harper Bazar».

Key words: corporeality, women's magazine, glamor, beauty, existential-somatic beauty. 